and the establishment of branches in various parts of Britain. The various grades of membership of the new Institute will be as follows : fellows (who will be entitled to use the letters F.I.W.Sc. after their names) ; associates (A.I.W.Sc.) ; certificated members; ordinary members; junior members; and patrons. The conditions for associateship include the higher c tificate of the Timber Development Associa. tion, Ltd., or the appropriate certificate of the Institute, or, at the discretion of the Council, a university degree in science, and also three years of experience in wood science; fellowships will be granted to associates at the discretion of the Council. The main condition for certificated membership is the thirdyear certificate of the Timber Development Association, Ltd. The subscription (which will include receipt of the journal) will be 3 guineas a year for fellows, associates and ordinary members ; 2 guineas a year for certificated members ; and 1 guinea a year for junior members. Firms, associations or corporations may become patrons by supporting the Institute financially, as also may individuals if they wish to subseribe more than the normal membership fee. Further information can be obtained from the honorary secretary of the Institute, c/o the Timber Development Association, Ltd., 21 College Hill, London, E.C.4.

\section{Higher Technological Education in London and the Home Counties}

The seventh annual report of the London and Home Counties Regional Advisory Council for Higher Technological Educetion, covering the year ended August 31, 1955 (pp. 40 ; from the Council, London; 1956), welcomes the Minister of Education's remark to the annual conference of the Association of Education Committees that he would not allow local feelings to spoil higher technical education, and points out that the Council's limited experience so far of planning courses in particular subjects regionally has not beon discouraging. In several instances, two or more authorities have jointly examined a known industrial demand and achieved a significant economy with greater efficiency. At the annual meeting of the Council, Sir Hugh Linstead criticized the Ministor's proposal to upgrade some twenty or thirty colleges and doubted particularly the possibility of providing even fifteen hundred additional technologists a year from the existing colleges and the possibility of properly staffing and equipping as many as twenty or thirty colleges at the higher level ; these criticisms and the subsequent discussion are summarized in the report. The Council has appointed Mr. L. C. Wooder to undertake a research project into the distribution of courses of higher technological education in the region, including an industrial survey of the region, surveys of technical education, communications in relation to the situation and 'catchment' areas of colleges and population trends, and a comparative study of those factors in relation to the distribution of courses. The Council has also recommended to local education authorities which are in mombership that a college should not initiate a sessional course of higher technological education unless it has every reason to suppose the course will continue to the end of the session and that if, owing to unforeseen circumstances, the course is terminated before the end of the session, the college should arrange for students to complete the course elsewhere with a minimum of inconvenience to tho student. Figures supplied by the Minister of Educa. tion for full-time degree and highor diploma students in technical colleges over the three years 1952-55 indicate a marked increase in those attending higher diploma courses in engineering, and the number working for M.Sc. or Ph.D. (internal) degrees during the period rose from 59 to 116 . The numbers of students for internal degrees fell from 1,641 to 1,369 and for external degrees from 761 to 544 .

\section{Parliamentary and Scientific Committee: Report for 1955}

The annual report for 1955 of the Parliamentary and Scientific Committee (pp. 22; from the Committee, 31 Palace Street, Westminster, London, S.W.1; 1956) provides the usual convenient record of the activities of the Committee during the year, including a list of addresses given to the general committee. Particular attention is given to problems connected with higher technological education and scientific man-power. During the second reading of the Agricultural Research Bill on December 13, representations regarding the present organization of veterinary research were made on behalf of the Committee by Mr. A. J. Champion, its joint honorary secretary, and by Mr. M. Philips Price, and further consideration will be given to this subject by the Committee this year. In view of the alarm expressed by several organizations as to the effect of the higher postal rates for scientific journals and publications, a questionnaire is being sent to all scientific organizations affiliated to the Committee to permit an assessment of the general position with a view to a formal and more detailed statement. During the passage through Parliament of the Rating and Valuation (Miscellaneous Provisions) Bill, the views of the scientific bodies were brought to the notice of the Government, and because of dissatisfaction about the rating position, expressed at a meeting of the Committee on July 12 , it was agreed to prepare $a$ comprehensive report for the Government on the rating position of research associations and scientific societies.

\section{Expenditure on Government Information Services}

A Whiтe Paper on "Government Information Services: Statement showing Estimated Expenditure, 1955-56" (Cmd. 9591. Pp. 4. London: H.M.S.O., 1955 ; 4d. net) gives the expenditure on home services as $£ 2,245,100$, compared with $£ 2,333,600$ in 1954-55, and on overseas services as $£ 10,495,950$, compared with $£ 10,231,700$. Of this sum, $£ 741,150$ is carried on the Central Office of Information's Vote, of which $£ 150,250$ and $\mathfrak{1 5 6 , 2 5 0}$ are for the Air Ministry and the War Office, respectively; these two Departments account for $£ 246,700$ and $£ 359,850$ of the total, respectively. Fistimated expenditure for the National Savings Committee $(£ 277,200)$ and the Road Fund of the Ministry of Transport and Civil Aviation $(£ 213,000)$ also exceeded $£ 200,000$. Of the Overseas Estimate, $£ 4,755,000$ is on account of the B.B.C. External Services as grant-in-aid from the Post Office, $£ 1,757,400$ as Foreign Office grant-in-aid to the British Council and $£ 2,289,800$ on behalf of the Foreign Office, including the Gorman Section. $£ 538,800$ goes to the British Council for the Colonial Office, and a further $£ 381,700$ for the Commonwealth Relations Office, while expenditure on behalf of the Colonial Office and the Commonwealth Relations Office is estimated at a further $£ 259,800$ and $£ \$ 94,700$, respectively. 